\title{
Buschke Lowenstein tumor in an elderly male
}

\author{
Perera $\mathrm{HP}^{1}$, Ilangarathne $\mathrm{A}^{2}$, De Silva $\mathrm{HML}^{-3}$, Mahendrarajah $\mathrm{K}^{4}$
}

\section{Key words}

Condylomata acuminata, human papillomavirus, Buschke Lowenstein tumor

\section{Introduction}

Though condylomata acuminata are a common sexually transmitted disease, Buschke-Lowenstein tumour (BLT), also known as giant condylomata acuminatum is very rare. Described first by Buschke in 1896, there are only few reported cases of BLT in medical literature and no reported cases from Sri Lanka. $(1,2)$

BLT is a slow growing, locally aggressive and destructive condition. Malignant transformation occurs in 40-60\%. (2) Chronic alcoholism and

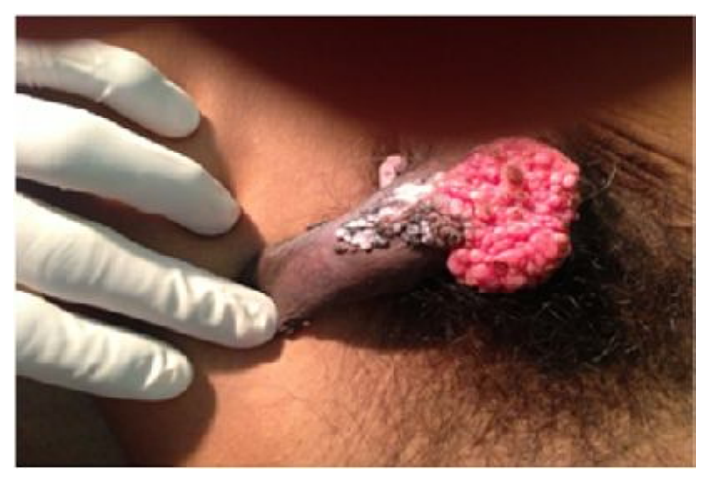

Figure1 .Giant polypoidial, cauliflower like lesion at the base of the penis

immune suppressive medicine increases the recurrence and malignant transformation. Human papillomavirus type 6 and 11 are implicated as causative agents. (3) Because of the slow growing nature, seeking medical attention is often late.
Managing BLT is challenging because of locally invasive and recurrent nature. Here we report a case of a BLT in a 61 year old male, successfully treated by surgical excision.

\section{Case Report}

A 61 year old male was seen at the sexually transmitted disease (STD) clinic due to a slowly growing tumour on his genital area for twenty years. Apart from ayurvedic treatment, he has not sought any treatment before. He is not on any long term medication. During young age he has had receptive anal sex.

He had a polypoidial, cauliflower like lesion (BLT) of about $6 \times 7 \mathrm{~cm}$ in size at the base of the penis (figure 1). In addition, there were condylomata accuminata at

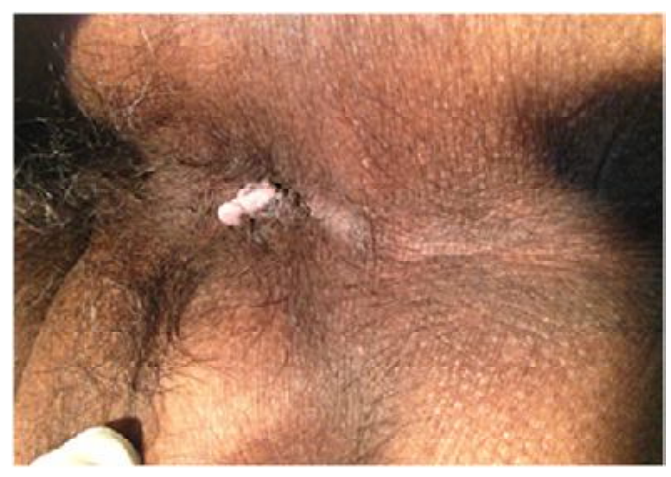

Figure2. Condylomata acuminata in the peri- anal region

perianal region and at urethral meatus (figure 2). $\mathrm{He}$ had no inguinal lymphadenopathy. Rest of the examination including digital examination of the rectum was normal. Magnetic resonance imaging (MRI) of the pelvis was not performed due to

${ }^{1}$ Venereologist, ${ }^{2}$ Medical officer, STD clinic Kalutara, ${ }^{3}$ Consultsnt Pathologist, ${ }^{4}$ Consultant Surgeon, District General Hospital, Kalutara 
unavailability. His Venereal Disease Research Laboratory (VDRL) test, Treponema pallidum particle agglutination (TPPA) test, human immune deficiency virus antibody test and hepatitis B surface antigen were negative. His full blood count, liver and renal function tests were normal.

The tumor was exercised under general anaesthesia. The patient made an uneventful recovery and was discharged home on the fourth post-operative day.

The biopsy revealed skin with an exophytic warty lesion lined by acanthotic epidermis showing marked papillomatosis. There was supra papillary parakeratosis and perinuclear halo in keratinocytes. No dysplasia was detected. The dermis was chronically inflamed. Features were consistent with condylomata acuminatum .

\section{Discussion}

BLT is a very rare sexually transmitted disease characterized by giant slow growing condylomata acuminatum. Most common clinical symptoms of BLT are pelvic pain, peri-anal secretion, ano-rectal bleeding and impairment of anal sphincter continence.Sometime patients may present with multiple sinuses or fistulae tracking deeply into the fascia, muscles or rectum. They may result in inflammation, infection or haemorrhage. However, our patient remained asymptomatic up to the time of presentation. BLT is considered pathologically to be in between condylomata acuminatum and perianal squamous cell carcinoma. Clinically giant condylomata acuminata, ordinary condylomas and squamous cell carcinomas present with similar findings and are only differentiated by histological examination. Even on histology, ordinary condylomata acuminata and giant condylomata acuminata share many similarities. Giant condylomata acuminatum is mainly recognized for its thicker stratum corneum and marked papillary proliferation. Very importantly, it tends to invade deeply, displacing the underlying tissues. For this reason giant condylomata acuminata are also known by some authors as verrucous carcinoma.(4) However, it rarely presents with histological features of malignancy such as infiltration of the basement membrane, frequent mitotic figures, lymphatic or angio-invasion and distant metastases. This represents the main difference with squamous cell carcinoma and giant condyloma acuminata. However squamous cell carcinoma and giant condylomata acuminata can co-exist in $30 \%$ to $56 \%$ of patients.(5)

Most efficient treatment method during the early period of the disease is surgical excision. Topical application of podophyllin has shown to be helpful for ordinary condylomata acuminata but does not control giant condylomata acuminata.(6) Systemic or topical chemotherapy and radiotherapy are given to patients with inoperable lesions. Large size, local invasion and high recurrence rate are the main challenges in the management. Recurrence rates as high as a $67 \%$ and mortality rate of $20 \%$ to $30 \%$ has been reported.(7) We were able to excise the lesion successfully, and there were no evidence of recurrence up to six months.

\section{Conclusion}

Early detection and excision will improve management of BLT. Histology is mandatory to exclude the possibility of squamous cell carcinoma.

\section{References}

1. Buschke A. Neisser's Sterokopicher Atlas. New York: Fischer; 1986.

2. Paraskevas KI, Kyriakos E, Poulios EE et al. Surgical managment of giant condylomata acuminatum of the perianal region. Dermatological Surgery 2007; 33(5):638-44.

3. Miranda AO, Garcia RJ, Gonalez ARC et al. Giant condylomata acuminatum. ActasUrol Esp. 2008; 32(9):32-39.

4. Bogomoleztz WV, Potet F, Molas G. Condyloma acuminatum, giant condyloma acuminatum and verrucous squamous carcinoma of the perianal and anorectal region: a continuous precancerous spectrum? Histopathology 1985; 9:1155-69. 
5. Chu QD, Vezeridis MP, Libbey NP et al. Giant condylomata acuminatum of the anorectal and perineal regions. Analysis of 42 cases. Dis Colon Rectum1994; 37:950-7.

6. Alexander RM, Kaminsky DB. Giant condyloma acuminata of the anus: case report and review of the literature. Dis colon rectum 1979; 22:5615 .

7. Creasman C, Haas PA, Fox TA Jr et al. Malignant transformation of anorectal giant condyloma acuminatum. Dis Colon Rectum 1989; 32:481-7. 